\title{
BUDAYA ORGANISASI SEBAGAI VARIABEL PREDIKTOR TERHADAP ORGANIZATIONAL CITIZENSIHP BEHAVIOR PADA KARYAWAN KOPERASI
}

\author{
Marhisar Simatupang \\ Email: marhisar@ubpkarawang.ac.id
}

Fakultas Psikologi Universitas Buana Perjuangan Karawang

\begin{abstract}
This study aims to determine the role of organizational culture on organization citizenship behavior in cooperative employees in Medan. The subjects of this study were 80 employees from three coorperatives in the Medan city. This research uses incidental sampling technique. Reserch data were obtained using two scales in the Likert scale model, namely organizational culture and organization citizenship behavior (OCB). The reliability of the scale of the organizational culture is 0.789 out of items and the reliability of the organization citizenship behavior $(O C B)$ scale is 0.727 out of 17 items. Research data were analyzed using simple regression correlation with the SPSS windows version 16.0 program and coefficient value obtained with an $R$ coefficient of 0.532 with a $P$ value of significance of $0.000<0.05$ with an $R$ coefficient of 0.532 , wich means that the organizational culture's contribution to organization citizenship behavior $(O C B)$ was $28.3 \%$ with a regression equation $Y=11.816+0.363$. The result means that there is a positive and significant role between organizational culture to organization citizenship behavior (OCB) in coorperative employee in Medan.
\end{abstract}

Keywords: organizational culture and organization citizenship behavior $(O C B)$.

Abstrak. Penelitian ini bertujuan untuk mengetahui peran budaya organisasi terhadap organization citizenship behavior (OCB) pada karyawan koperasi di kota Medan Kecamatan Medan Tuntungan. Subjek penelitian ini adalah 80 orang karyawan dari tiga koperasi yang ada di kecamatan Medan Tuntungan. Penelitian ini menggunakan teknik sampling aksidental. Data penelitian diperoleh dengan menggunakan dua skala dalam model skala Likert, yaitu skala budaya organisasi dan organization citizenship behavior (OCB). Reliabilitas skala budaya organisasi adalah 0,798 dari 22 item dan reliabilitas skala organization citizenship behavior $(O C B)$ adalah 0,727 dari 17 item. Data dalam penelitian ini dianalisis dengan menggunakan korelasi regresi sederhana dengan program SPSS windows versi 16.0 dan diperoleh nilai koefisien dengan koefisien $\mathrm{R}$ sebesar 0.532 dengan nilai $\mathrm{p}$ signifikansi sebesar $0.000<0.05$ dengan koefisien $\mathrm{R}$ sebesar 0.532 , yang memiliki arti bahwa kontribusi budaya organisasi terhadap OCB sebesar 28.3\% dengan persamaan regeresi $\mathrm{Y}=11.816+0.363$. Hasil ini berarti ada peran yang positif dan signifikan antara budaya organisasi terhadap organization citizenship behavior $(O C B)$ pada anggota Koperasi di kota Medan.

Kata Kunci: Budaya organisasi, organization citizenship behavior.

8 | Psychophedia Jurnal Psikologi Universitas Buana Perjuangan Karawang 


\section{Pengantar}

Koperasi adalah suatu badan usaha yang dimiliki dan dioperasikan oleh para anggotanya untuk memenuhi kepentingan bersama di bidang ekonomi. Selain itu ada juga yang mengatakan pengertian koperasi adalah suatu badan hukum yang di bentuk atas asas kekeluargaan dimana melanjutkan adalah untuk mensejahterakan para anggotanya. Dalam hal ini, koperasi membentuk dimana kegiatannya berdasarkan prinsip gerakan ekonomi kerakyatan. Menurut Arifinal Chaniago (1984), koperasi adalah sebuah perkumpulan yang beranggotakan orang-orang atau badan hukum, yang memberikan kebebasan pada anggota untuk masuk dan keluar, dengan bekerja sama secara kekeluargaan berjalan usaha untuk meningkatkan kesejahteraa para anggotanya. Berdasarkan pengertian koperasi tersebut maka, tujuan pembentukan koperasi adalah untuk meningkatkan taraf hidup anggota koperasi dan masyarakat di sekitarnya, untuk membantu seumur hidup para anggota koperasi dalam hal ekonomi, membantu pemerintah dalam mewujudkan masyarakat yang adil dan makmur serta koperasi menghadiri juga dalam membangun tatanan perekonomian nasional. Untuk mencapai tujuan tersebut maka setiap koperasi di Kecamatan Medan Tuntungan kota Medan membutuhkan partisipasi aktif dari para anggota.

Kasus yang terjadi adalah pada salah satu koperasi yang ada di kecamatan Medan Tuntungan dihadapkan pada realitas kekinian dimana anggota koperasi terjerumus dalam pola individualistik dengan gaya hidup yang hedonis, hal ini terlihat dari hasil observasi yang dilakukan pada tanggal 29 September 2019, ditemukan rendahnya tingkat partisipasi anggota koperasi dalam setiap kegiatan yang diselenggarakan oleh koperasi serta kurangnya rasa kepedulian terhadap sesama angota yang mengalami kesulitan. Hal lain yang menjadi permasalahan adalah rasa memiliki koperasi yang rendah ditunjukan oleh peran anggota dalam menjalankan tugas dan tanggung jawabnya, seperti menunda penyetoran ke koperasi, molor waktu, serta tingkat gotongroyong yang rendah.

Berdasarkan hasil wawancara yang telah dilakukan pada 5 orang karyawan koperasi di Medan, dapat disimpulkan bahwa masalah yang terjadi dalam koperasi di kecamatan Medan Tuntungan adalah minimnya partisipasi, kurangnya kepekaan dalam melakukan sesuatu tanpa menunggu instruksi, kesukarealaan dalam mengerjakan tugas yang tertunda di luar deskripsi kerjanya, kurangnya kebersamaan dan team work serta semangat gotong royong yang rendah, kurangnya partisipasi anggota dalam berkegiatan dan melaksanakan kewajiban sebagai anggota koperasi. Perilaku-perilaku tersebut tentunya akan menghambat kerjakerja taktis koperasi dalam mencapai visi serta misinya.

Perilaku di atas menunjukkan kurangnya organizational citizenship behavior $(O C B)$ dalam koperasi yang ada di kecamatan Medan Tuntungan. Menurut Ahmad dan Tanzin (Mahendra \& Surya, 2017:46) $O C B$ merupakan bentuk kegiatan sukarela dari anggota organisasi yang mendukung fungsi organisasi, sehingga 
perilaku ini lebih bersifat menolong yang diekspresikan dalam bentuk tindakantindakan yang menunjukkan sikap tidak mementingkan diri sendiri dan perhatian pada kesejahteraan orang lain maupun organisasi. Menurut Yaghoubi, dkk (Pemayuni \& Wibawa, 2017:50) organizational citizenship behavior juga dikenal sebagai perilaku extra role yang merupakan tindakan melebihi persyaratan dari pekerjaan yang seharusnya, dimana peran ekstra di sini berarti kontribusi individu yang melebihi atau melampaui perannya dan tidak menggunakan system reward.

Menurut Robbins (Husodo, 2018:1) contoh perilaku yang termasuk kelompok $O C B$ adalah membantu rekan seorganisasi yang membutuhkan bantuan tanpa menunggu instruksi dari pimpinan, sukarela melakukan kegiatan ekstra pada organisasi atas kemauan sendiri, menghindari konflik dengan sesama anggota dalam organisasi, melindungi properti organisasi, menghargai peraturan yang berlaku yang ada dalam organisasi, toleransi pada situasi yang kurang ideal/menyenangkan di dalam organisasi, serta tidak membuang-buang waktu.

Menurut Sulistyowati (2014:2), salah satu faktor yang mempengaruhi organizational citizenship behavior (OCB) adalah budaya organisasi. Setiap organisasi memiliki budaya yang berbeda satu sama lain. Menurut Robbins (Romli, 2014:195) budaya organisasi mengacu pada suatu sistem makna bersama yang dianut oleh anggota-anggotanya dan yang membedakan antara satu organisasi dengan lainnya.
Juni 2020 - November 2020

Budaya organisasi atau corporate culture sering diartikan sebagai nilai-nilai, simbol-simbol yang dimengerti dan dipatuhi bersama, yang dimiliki suatu organisasi sehingga anggota organisasi merasa satu keluarga dan menciptakan suatu kondisi anggota organisasi tersebut merasa berbeda dengan organisasi lain. Menurut Widjaja (Ardiansyah, 2017:2) budaya organisasi merupakan kepribadian yang ada pada organisasi, pada banyak organisasi peran budaya organisasi sangatlah menonjol, karena budaya organisasi akan membentuk karakter anggota organisasi dalam melakukan pekerjaannya, dengan kata lain budaya organisasi merupakan pola asumsiasumsi dasar yang oleh suatu kelompok telah ditemukan, dibuka, atau dikembangkan melalui belajar untuk memcahkan masalahmasalah adaptasi eksternal dan integrasi internal. Berdasarkan pemaparan di atas, diajarkan kepada anggota-anggota baru sebagai cara yang benar untuk memandang, berpikir dan merasa dalam kaitannya dengan masalah-masalah yang ada.

Penelitian yang dilakukan oleh Sari dan Hajriani (2015) tentang pengaruh karakteristik budaya organisasi terhadap organizational citizenship behavior (Studi kasus Rumah Sakit Umum Citra Bunda Medical Centre Padang), hasil penelitian menunjukkan terdapat pengaruh positif variabel jarak dari manajemen sebesar 0,089 dengan nilai signifikan sebesar $0,286>0,05$ terhadap OCB, terdapat pengaruh positif dan signifikan variabel percaya pada rekan sebesar 0.467 dengan nilai signifikan sebesar $0,028<0,05$ terhadap OCB, terdapat pengaruh positif dan tidak signifikan 
variabel keteraturan sebesar 0,093 dengan nilai signifikan sebesar $0.662>0,05$ terhadap OCB, terdapat pengaruh yang positif dan signifikan variabel permusuhan sebesar 0,526 dengan nilai signifikan 0,045<0,05 terhadap OCB dan terdapat pengaruh yang positif dan tidak signifikan variabel integrasi sebesar 0,207 dengan nilai signifikan 0,338>0,05 terhadap OCB.

Penelitian serupa juga dilakukan oleh Puspita, dkk (2013) tentang pengaruh komitmen organisasi, kepuasan kerja dan budaya organisasi terhadap organizational citizenship behavior (OCB). Hasil penelitian ini menunjukkan bahwa komitmen organisasi berpengaruh positif dan signifikan terhadap kepuasan kerja, budaya organisasi berpengaruh positif yang signifikan terhadap kepuasan kerja, komitmen organisasi memiliki pengaruh positif dan signifikan terhadap organizational citizenship behavior (OCB).

\section{Landasan Teori}

Organizational Citizenship Behavior (OCB).

Menurut

Resckhe

(1997)

organizational citizenship behavior merupakan kontribusi individu dalam melebihi tuntutan peran di tempat kerja. OCB ini melibatkan beberapa perilaku meliputi perilaku suka menolong orang lain, menjadi volunteer untuk tugas-tugas ekstra, patuh terhadap aturan-aturan dan prosedurprosedur di tempat kerja. Organ (Podsakoff, dkk, 2000) mendefinisikan OCB sebagai perilaku individual yang bersifat bebas (discretionary), yang tidak secara langsung dan eksplisit mendapat penghargaan dari sistem imbalan formal dan yang secara keseluruhan mendorong keefektifan fungsifungsi organisasi. Bersifat bebas dan sukarela, karena perilaku tersebut tidak diharuskan oleh persyaratan peran atau deskripsi jabatan, yang secara jelas dituntut berdasarkan kontrak dengan organisasi melainkan sebagai pilihan personal.

Terdapat lima dimensi OCB menurut Organ (2006) adalah sebagai berikut: a). Altruism, perilaku karyawan dalam menolong rekan kerjanya yang mengalami kesulitandalam situasi yang sedang dihadapi baik mengenai tugas dalam organisasi maupun masalah pribadi orang lain. Dimensi ini mengarah kepada memberi pertolongan yang bukan merupakan kewajiban yang ditanggungnya. b). Conscientiousness, perilaku yang ditunjukkan dengan berusaha melebihi yang diharapkan perusahaan. Perilaku sukarela yang bukan merupakan kewajiban atau tugas karyawan. Dimensi ini menjangkau jauh diatas dan jauh ke depan dari panggilan tugas. c). Sportmanship, perilaku yang memberikan toleransi terhadap keadaan yang kurang ideal dalam organisasi tanpa mengajukan keberatan-keberatan. Seseorang yang mempunyai tingkatan yang tinggi dalam spotmanship akan meningkatkan iklim yang positif diantara karyawan, karyawan akan lebih sopan dan bekerja sama dengan yang lain sehingga akan menciptakan lingkungan kerja yang lebih menyenangkan. d). Courtessy, menjaga hubungan baik dengan rekan kerjanya agar terhindar dari masalah-masalah interpersonal. Seseorang yang memiliki 
Juni 2020 - November 2020

dimensi ini adalah orang yang menghargai dan memperhatikan orang lain. e). Civic Virtue, perilaku yang mengindikasikan tanggung jawab pada kehidupan organisasi (mengikuti perubahan dalam organisasi, mengambil inisiatif untuk merekomendasikan bagaimana operasi atau prosedur-prosedur organisasi dapat diperbaiki, dan melindungi sumber-sumber yang dimiliki oleh organisasi). Dimensi ini mengarah pada tanggung jawab yang diberikan organisasi kepada seorang untuk meningkatkan kualitas bidang pekerjaan yang ditekuni.

Menurut Luthans (2006) OCB memiliki banyak bentuk tetapi bentuk utamanya dapat disimpulkan sebagai berikut: altruisme (misalnya, membantu rekan kerja tidak sehat), kesungguhan (misalnya, lembur untuk menyelesaikan proyek), kepentingan umum (misalnya,rela mewakili perusahaan untuk program bersama), sikap positif (misalnya, ikut menanggung kegaalan proyek tim yang mungkin akan berhasil dengan mengikuti nasihat anggota), dan sopan (misalnya, memahami dan berempetai walaupun saat dikritik).

\section{Budaya Organisasi}

Budaya dalam suatu organisasi merupakan karakteristik semangat atau suasana (spirit) dan kepercayaan (belief) yang dilakukan di dalam organisasi tersebut (Torrington, 1994:31). Budaya yang ada pada suatu organisasi akan berbeda dengan organisasi lainnya. Lebih lagi organisasi yang ada pada negara yang berbeda. Oleh karena itu, kita perlu memahami perbedaan budaya antarnegara yang sangat beragam sehingga dapat mengelola perbedaan tersebut.

Menurut Davis (Lako, 2004:29) budaya organisasi merupakan pola keyakinan dan nilai-nilai organisasi yang dipahami, dijiwai dan dipraktekkan oleh organisasi sehingga pola tersebut memberikan arti tersendiri dan menjadi dasar aturan berperilaku dalam organisasi. Hal yang sama juga diungkapkan oleh Mangkunegara (2005:113) yang menyatakan bahwa budaya organisasi adalah seperangkat asumsi atau sistem keyakinan, nilai-nilai, dan norma yang dikembangkan dalam organisasi yang dijadikan pedoman tingkah laku bagi anggota-anggotanya untuk mengatasi masalah adaptasi eksternal dan internal.

Menurut Kast (Robins, 2005) memberikan definisi budaya organisasi sebagai sistem nilai dan kepercayaan yang dianut bersama yang berinteraksi dengan orang-orang suatu perusahaan, strukur organisasi dan sistem pengawasan untuk menghasilkan norma-norma perilaku. Sedangkan Schein (Gibson et.al, 2005) mendefinisikan budaya sebagai pola dari asumsi dasar yang telah ditentukan atau dikembangkan untuk mempelajari cara-cara berintegrasi, yang telah berfungsi dengan baik yang telah dianggap baru oleh karenanya harus diajarkan kepada anggota baru sebagai cara yang besar untuk memikirkan, memandang dan merasa berkepentingan dengan masalah tersebut. Berbagai definisi tentang budaya perusahaan tersebut menyimpulkan betapa budaya 
perusahaan sangat mempengaruhi berbagai aspek kehidupan bisnis.

Budaya organisasi atau perusahaan bersifat sangat persuasif dan mempengaruhi hampir keseluruhan aspek kehidupan organisasi. Demikian juga budaya organisasi mampu menumpulkan atau membelokkan dampak perubahan organisasi yang sudah direncanakan secara matang. Pada dasarnya, budaya organisasi atau perusahaan menjelma dalam berbagai wujudnya dan karena bisa mendukung atau menghambat perubahan. Budaya organisasi dimanifestasikan dalam dua bentuk yaitu konkrit dan abstrak. konkrit, yaitu hal ini bisa dilihat dari cara anggota melayani konsumen, cara berpakaian anggotanya. Dan cara berkomunikasi baik antara atasan dan bawahan maupun rekan sekerja. Abstrak, yaitu hal ini bisa dilihat secara kasat mata. Bentuk ini merupakan bagian yang paling sukar diubah karena terdapat pada sisi kognitif sistem nilai sebuah budaya perusahaan. Disini budaya perusahaan berbentuk ide atau gagasan anggota organisasi tentang lingkungannya yang relatif stabil dari waktu ke waktu walau anggota berubah.

Budaya organisasi pada dasarnya tidak dapat dilepaskan dari konteks budaya secara umum yang ada dalam masyarakat. Menurut Kast (Robbins, 2003) dimana budaya organisasi merupakan seperangkat sistem nilai dan kepercayaan yang dianut bersama yang berinteraksi dengan orangorang suatu perusahaan, strukur organisasi dan sistem pengawasan untuk menghasilkan norma-norma perilaku, maka sebenarnya budaya organisasi kalau merupakan bagian dari budaya umum yang berkembang dalam masyarakat dalam lingkup spesifik yang bersifat abstrak. Atas dasar itu, pemahaman terhadap unsur-unsur dan karakteristik budaya organisasi dalam suatu organisasi maka merupakan hal yang sangat penting dalam mempelajari atau mengkajinya.

Menurut Gibson et.al (2005), budaya organisasi perusahaan mempunyai lima karakterisktik: 1). Mempelajari, yaitu kultur diperlukan dan diwujudkan dalam belajar, observasi dan pengalaman. 2). Saling berbagi, yaitu individu dalam kelompok, keluarga saling berbagi kultur dan pengalaman. 3). Transgenerasi, merupakan kumulatif dan melampaui satu generasi ke generasi berikutnya. 4). Persepsi pengaruh, yaitu membentuk perilaku dan struktur bagaimana seseorang menilai dunia. 5). Adaptasi, yaitu kultur didasarkan pada kapasitas seseorang berubah atau beradaptasi.

\section{Koperasi}

Menurut Fay (Hendrojogi, 2012:20) koperasi adalah suatu perserikatan dengan tujuan berusaha bersama yang terdiri dari atas mereka yang lemah dan diusahakan selalu dengan semangat tidak memikirkan diri sendiri sedemikian rupa, sehingga masing-masing sanggup menjalankan kewajibannya sebagai anggota dan mendapat imbalan sebanding dengan pemanfaatan mereka terhadap organisasi. Djojohadikoesoemo (Hendrojogi, 2012:21) koperasi adalah perkumpulan manusia seorang-seorang yang dengan sukanya sendiri hendak berkerja sama untuk memajukan ekonominya. 
Menurut Undang-Undang Nomor 17 Tahun 2012 koperasi adalah badan hukum yang didirikan oleh orang perseorangan atau badan hukum koperasi, dengan pemisahan kekayaan para anggotanya sebagai modal untuk menjalankan usaha, yang memenuhi aspirasi dan kebutuhan bersama dibidang ekonomi, sosial, dan budaya sesuai dengan nilai dan prinsip koperasi.

Menurut Undang-Undang Nomor 17 Tahun 2012 ada empat jenis koperasi sebagai berikut: 1). Koperasi konsumen, menyelenggarakan kegiatan usaha pelayanan di bidang penyediaan barang kebutuhan anggota dan non anggota. 2). Koperasi produsen, menyelenggarakan kegiatan usaha pelayanan di bidang pengadaan sarana produksi dan pemasaran produksi yang dihasilkan anggota kepada anggota dan non anggota. 3). Koperasi jasa, menyelenggarakan kegiatan usaha pelayanan jasa non simpan pinjam yang diperlukan oleh anggota dan non anggota. 4). Koperasi simpan pinjam, menjalankan usaha simpan pinjam sebagai satusatunya yang melayani anggota.

Menurut Hendrojogi (2012:46) prinsip-prinsip koperasi adalah pedoman bagi koperasi-koperasi dalam melaksanakan nilai-nilai koperasi dalam praktik. Prisnipprinsip koperasi tersebut adalah sebagai berikut: 1) Keanggotaan yang sukarela dan terbuka. Koperasi adalah organisasi yang bersifat sukarela, terbuka bagi semua orang yang bersedia menggunakan jasa-jasanya dan bersedia menerima tanggung jawab keanggotaan, tanpa membedakan jenis kelamin (gender), latar belakang sosial, ras, politik atau agama. 2). Pengawasan
Juni 2020 - November 2020 demokratis oleh anggota. Koperasi adalah organisasi demokratis yang diawasi oleh para anggotanya, yang secara aktif menetapkan kebijakan dan membuat keputusan. Pria dan wanita yang dipilih sebagai wakil anggota bertanggung jawab kepada rapat anggota. 3). Partisipasi anggota dalam kegiatan ekonomi. Para anggota memberikan kontribusi permodalan koperasi secara adil dan melakuka pengawan secara demokratis (terhadap modal tersebut). Setidak-tidaknya sebagian dari modal itu adalah milik bersama koperasi. Apabila ada, para anggota biasanya menerima kompensasi yang terbatas atas modal yang diisyaratkan untuk menjadi anggota. 4). Otonomi dan kemandirian (Independence). Koperasi adalah organisasi otonom, menolong diri sendiri serta diawasi oleh para anggotanya. Apabila koperasi mengadakan perjanjian dengan organisasi lain, termasuk pemerintah atau modal dari sumber luar, koperasi melakukanya berdasarkan persyaratan yang menjamin pengawasan demokratis oleh para anggotanya dan yang mempertahankan otonomi mereka. 6). Pendidikan, pelatihan dan penerangan. Koperasi memberikan pendidikan dan pelatihan bagi para anggota, wakil-wakil anggota yang dipilih oleh rapat anggota serta para menajer dan karyawan, agar mereka dapat melakukan tugasnya lebih efektif bagi perkembangan koperasinya. Mereka memberikan penerangan kepada masyarakat umum khususnya pemuda dan para pembentuk opini dimasyarakat tentang hakikat perkoperasian dan manfaat berkoperasi. 7). Kerja sama antar koperasi. Koperasi melayani para anggotanya secara 
kolektif dan memperkuat gerakan koperasi dengan berkerja sama melalui organsasi koperasi, nasional, regional dan internasional. 8). Kepedulian terhadapt masyarakat. Koperasi melakukan kegiatan untuk pengembangan masyarakat sekitarnya secara bekelanjutan, melalui kebijakankebijakan yang diputuskan oleh rapat anggota.

\section{Metode Penelitian}

Penelitian ini menggunakan pendekatan kuantitatif. Dalam penelitian ini peneliti mengambil sampel dengan menggunakan teknik sampling aksidental. Menurut Sugiyono (2001:60) sampling aksidental adalah teknik penentuan sampel berdasarkan kebetulan, yaitu siapa saja yang secara kebetulan bertemu dengan peneliti dapat digunakan sebagai sampel, bila dipandang orang yang kebetulan itu cocok sebagai sumber data. Artinya peneliti langsung mengumpulkan data dari unit sampling yang ditemui sampai jumlah yang diharapkan peneliti terpenuhi. Dalam hal ini jumlah sampling sebagai objek penelitian adalah 80 orang. Skala yang digunakan dalam penelitian ini adalah skala budaya organisasi dan skala organizational citizenship behavior. Skala yang digunakan dalam penelitian ini adalah skala Likert Modifikasi. Skala Likert digunakan untuk mengukur sikap, pendapat, persepsi seseorang tentang fenomena sosial. Analisis data dalam penelitian ini diolah dengan menggunakan bantuan program SPSS for windows version 24.0.

\section{Hasil Dan Pembahasan Penelitian}

Juni 2020 - November 2020

Hipotesis dalam penelitian ini adalah ada peran budaya organisasi terhadap organizational citizenship behavior, berdasarkan hasil uji hipotesis menunjukkan bahwa terdapat peran positif yang signifikan antara Budaya Organisasi terhadap organizational citizenship behavior, dengan nilai $\mathrm{p}$ signifikansi sebesar $0.000<0.05$ yang berarti ada peran positif antara budaya organisasi terhadap organizational citizenship behavior (OCB) pada karyawan koperasi di Kecamatan Medan Tuntungan. Artinya semakin tinggi budaya organisasi, maka semakin tinggi organizational citizenship behavior (OCB). Begitu juga sebaliknya, semakin rendah budaya organisasi, maka semakin rendah organizational citizenship behavior (OCB), yaitu dengan koefisien R sebesar 0.532, yang memiliki arti bahwa kontribusi budaya organisasi terhadap OCB sebesar $28.3 \%$ dengan persamaan regeresi $\mathrm{Y}=11.816+$ 0.363 , ini berarti Ho ditolak dan $\mathrm{Ha}$ diterima.

Berdasarkan hasil penelitian ini, budaya organisasi pada karyawan koperasi di Kecamatan Medan Tuntungan mencapai $28.3 \%$ yang memberikan kontribusi positif terhadap OCB. Hal ini menunjukan budaya organisasi sebagai filosofi dasar organisasi yang memuat keyakinan, norma-norma, dan nilai-nilai bersama yang menjadi karakteristik inti tentang bagaimana melakukan sesuatu dalam organisasi, mampu dipahami dan dimaknai oleh anggota koperasi, sehingga berpengaruh pada perilaku anggota organisasi koperasi di 
Kecamatan Medan Tuntungan seperti: menolong anggota lain, gotong royong atau kerjasama tim yang baik, mencegah timbulnya masalah dalam koperasi, bersedia melakukan tugas lebih tanpa mengeluh, toleransi terhadap keadaan yang kurang ideal dalam koperasi, berpartisipasi dalam kegiatan yang diadakan oleh koperasi, serta mampu bertanggung jawab dan konstruktif, yang merupakan bagian dari organizational citizenship behavior pada anggota koperasi di Kecamatan Medan Tuntungan. Sementara itu $71,7 \%$ di pengaruhi oleh faktor iklim organisasi, kepribadian, suasana hati (mood), persepsi terhadap dukungan organisasi dan kualitas interaksi. Hal ini telah didukung oleh beberapa penelitian sebelumnya.

Penelitian yang dilakukan oleh Oemar (2013:73) Penerapan budaya organisasi berkorelasi positif dan signifikan terhadap OCB yang tercermin dalam bentuk membantu rekan kerja, membantu memberikan pelayanan kepada siapapun, bersedia menyelesaikan tugas dan pekerjaan tanpa diminta, mengikuti perubahan dan perkembangan organisasi,tepat waktu dalam melaksanakan aktivitas kerja, keterlibatan dalam fungsi dan kegiatan organisasi,memiliki rasa toleransi, dan tidak mengeluh atas beban pekerjaan yang diberikan. Penelitian yang dilakukan oleh Sulistyowati (2014:4) menunjukan budaya organisasi memberikan kontribusi positif terhadap OCB, yang artinya semakin tinggi budaya organisasi maka akan semakin tinggi pula OCB, Sehingga hal ini mencerminkan bahwa memiliki budaya organisasi yang tinggi menjadi salah satu hal yang dapat memunculkan perilaku OCB. Penelitian yang dilakukan oleh Husodo (2018:6) tentang pengaruh budaya organisasi terhadap organizational citizenship behavior (OCB) dengan kepuasan kerja sebagai variabel intervening pada PT Jatim Indo Lestari, menunujukan hasil bahwa budaya organisasi berpengaruh positif dan signifikan terhadap organizational citizenship behavior (OCB). Temuan ini memberikan bukti secara empiris bahwa budaya organisasi merupakan sebuah konsep sebagai kunci keberhasilan suatu organisasi dalam mencapai tujuannya.

Dari hasil penelitian yang telah dilakukan dan dijabarkan, dapat dilihat bahwa budaya organisasi di koperasi memberikan pengaruh yang cukup tinggi terhadap organizational citizenship behavior $(O C B)$ pada anggota koperasi di Kecamatan Medan Tuntungan. Manfaat dari penerapan budaya organisasi yang baik adalah dapat meningkatkan jiwa gotong royong, meningkatkan kebersamaan,saling terbuka satu sama lain, meningkatkan jiwa kekeluargaan, membangun komunikasi yang lebih baik, yang sebagian besar merupakan bagian dari organizational citizenship behavior (OCB). Organizational citizenship behavior yang dimiliki oleh anggota koperasi di Sikka berkembang seiring dengan proses sosialisasi dan nilai-nilai yang ada pada koperasi (budaya organisasi), ketika nilai-nilai itu memiliki makna yang kuat maka organizational citizenship behavior akan muncul dalam perilaku anggota koperasi, hal ini secara tidak langsung berpengaruh kepada kualitas pelayanan yang diberikan oleh anggota koperasi. Artinya ketika nilai-nilai itu memiliki makna yang kuat maka 
organizational citizenship behavior akan muncul dalam perilaku anggota koperasi.

\section{Kesimpulan}

Berdasarkan hasil penelitian yang terdapat pengaruh yang signifikan dengan arah hubungan positif antara budaya organisasi dan organizational citizensihp behavior $(O C B)$ pada anggota koperasi di Kabupaten Medan Tuntungan yang ditunjukan dengan nilai $\mathrm{p}$ signifikansi sebesar $0.000<0.05$ dengan kontribusi budaya organisasi terhadap OCB sebesar 28.3\% maka Ho ditolak dan Ha diterima sehingga hipotesis pada penelitian ini diterima, yaitu ada pengaruh positif antara budaya organisasi terhadap organizational citizenship behavior (OCB) pada anggota koperasi di Medan Tuntungan. Artinya semakin tinggi budaya organisasi, maka semakin tinggi organizational citizenship behavior (OCB). Begitu juga sebaliknya, semakin rendah budaya organisasi, maka semakin rendah organizational citizenship behavior.

\section{Kepustakaan}

Alfian, L. (2014). Pengaruh budaya organisasi dan loyalitas kerja dengan intensi turnover pada karyawan PT. Cipaganti Heavy Equipment Samarinda. E-Journal Psikologi, 2(1), 12-20.

Azwar, S. (2005). Metode penelitian. Yogyakarta: penerbit pustaka pelajar.

Ardiansyah. (2017). Pengaruh budaya organisasi dan iklim organisasi terhadap
Juni 2020 - November 2020

loyalitas kerja karyawan. Jom Fisip, 4(1).

Ahmadi, F. (2010). Survey relationship between OCB and internal \& external factors impact on OCB. European Journal of Social Sciences, 16(3).

Andriani, G., Asad, D., dan Diah, S. (2012). Organizational citizenship behavior dan kepuasan kerja pada karyawan. Jurnal Penelitian Psikologi, 03(1), 341-345.

Cindy, V. B. A. K. T., Dundu, R. J. M. (2016). Pengaruh pendayagunaan sumber daya manusia (Tenaga kerja) terhadap hasil pekerjaan (Studi kasus perumahan taman mapanget raya (Tamara) Mandagi. Jurnal Sipil Statik, 4(1), 2337-6732

Cahayu, P. A. S., dan Adnyani, I. G. A. D. (2015). Pengaruh keadilan organisasi terhadap kepuasan kerja dan organizational citizenship behavior pada karyawan toko Nyoman. E-Jurnal Manajemen Unud, 4(11), 3738 - 3765.

Dika, M., Ketut, S. (2017). Pengaruh iklim organisasi, motivasi kerja dan keadilan organisasi terhadap organizational citizenship behavior (OCB). E-Jurnal Manajemen Unud, 6(9).

Dyah, P., Rusdarti, Suparjo. (2013). Pengaruh komitmen organisasi, kepuasan kerja dan budaya organisasi terhadap organizational citizenship behavior (OCB). Jurnal Ilmiah Dinamika Ekonomi dan Bisnis, 1(1).

Hajriani, I., Sari, K. (2015). Pengaruh karakteristik budaya organisasi terhadap organizational citizenship behavior (Studi kasus Rumah Sakit Umum Citra Bunda Medical Centre Padang). Journal of Economic and Economic Education, $3(2)$.

Hakim, A., Hadipopo, A. (2015). Peran kepemimpinan dan budaya organisasi terhadap kinerja sumber daya manusia di Wawotobi. Ekobis, 16, (1).

17 | Psychophedia Jurnal Psikologi Universitas Buana Perjuangan 
Husodo, P. (2018). Pengaruh budaya organisasi terhadap organizational citizenship behavior (ocb) dengan kepuasan kerja sebagai variabel intervening pada PT. Jatim Indo Lestari. Agora, 6(1).

Jex, S., and Britt, T. (2007). Organizational psychology a scientist-practitioner approach. printed in the United States of America. Includes bibliographical references and index.

Kreitner, R., dan Kinicki, A. (2000). Prilaku organisasi. Jakarta: Penerbit Salemba Empat.

Lila, T., Ari, P., Hari, S. (2012). Pengaruh budaya organisasi dan gaya kepemimpinan transformasional terhadap kinerja karyawan melalui disiplin kerja pada karyawan harian SKT Megawon II PT. Djarum Kudus. Diponegoro Journal of Social and Politic, 2(3).

Lubis, S. (2015). Pengaruh iklim organisasi dan komitmen organisasi terhadap pembentukan organizational citizenship behavior (OCB) karyawan dalam rangka peningkatan kinerja. E-Jurnal Apresiasi Ekonomi, 3(2).

Mahendra, D., Surya, K. (2017). Pengaruh iklim organisasi, motivasi kerja dan keadilan organisasi terhadap organizational citizenship behavior (OCB). E-Jurnal Manajemen Unud, $6(9)$.

Nawangsari, C. I. (2014). Pengaruh kepemimpinan transformasional, pengawasan dan transparansi terhadap kinerja (Studi pada satuan kerja perangkat Daerah Pemerintah Daerah Kab/Kota di Bakorwil IV Provinsi Jawa Timur). Disertasi. Universitas Brawijaya.

Nadeak, B. (2016). Pengaruh budaya organisasi terhadap organizational
Juni 2020 - November 2020 citizenship behavior (OCB) dosen di Universitas Kristen indonesia (UKI).

Oemar, Y. (2013). Pengaruh budaya organisasi, kemampuan kerja dan komitmen organisasi terhadap organizational citizenhsip behaviour $(O C B)$ pada Pegawai BAPPEDA Kota Pekanbaru. Jurnal Aplikasi Manajemen, 11(1).

Putu, A., Sinta, A., Surya, P. (2017). Pengaruh budaya organisasi terhadap organizational citizenship behavior dengan pemediasi komitmen afektif di sekretariat Kabupaten Badung. E-Jurnal Ekonomi dan Bisnis Universitas Udayana.

Pemayuni, T., Wibawa, A. (2017). Pengaruh stres kerja dan budaya organisasi terhadap organizational citizenship behavior (OCB). E-Jurnal Manajemen Unud, 6(9).

Putra, M. (2014). The influence of organizational culture on employee performance in toserba xyz Bandung. EProceeding of Management, 1(3).

Pressindo. (2001). Pokok-pokok ajaran Marhaenisme Bung Karno. Yogyakarta: Penerbit Media Pressindo

Romli. (2014). Komunikasi organisasi lengkap, edisi revisi. Jakarta: Penerbit Grasindo

Rini, P. (2013). Pengaruh komitmen organisasi, kepuasan kerja dan budaya organisasi terhadap organizational citizenship behavior (OCB). Jurnal Ilmiah Dinamika Ekonomi dan Bisnis $1(1)$.

Rahmatun, A., dan Kristyanto, A. (2014). Pengaruh gaya kepemimpinan transformasional dan komitmen organisasi terhadap organizational citizenship behavior. Jurnal Ilmu Manajemen, 2(1).

Rahmatun, T. A., dan Anang, K. (2014). Pengaruh gaya kepemimpinan

18 | Psychophedia Jurnal Psikologi Universitas Buana Perjuangan 
transformasional dan komitmen organisasi terhadap organizational citizenship behavior. Jurnal Ilmu Manajemen, 2(1).

Saleh, L. (2015). Pengaruh iklim organisasi dan komitmen organisasi terhadap pembentukan organizational citizenship behavior (OCB) karyawan dalam rangka peningkatan kinerja. E-Jurnal Apresiasi Ekonomi, 3(2).

Sulistyowati, F. E. (2014). Hubungan antara budaya organisasi dengan organizational citizenship behaviour (ocb) pada pegawai dinas pendidikan Kota Cilegon. Skripsi. Surakarta: Universitas Muhammadiyah Surakarta.

Sugiyono. (2011). Metode penelitian kuantitatif, kualitatif dan kombinasi. Bandung: Penerbit Alfabeta.

Tangkas, P., Artha, W. (2017). Pengaruh stres kerja dan budaya organisasi
Juni 2020 - November 2020 terhadap organizational citizenship behavior.

Umar, H. (2007). Metode penelitian untuk skripsi dan tesis bisnis. Jakarta: PT. Raja Grafindo Persada

Vannecia M, Soegandhi, Eddy M, Sutanto, Roy S. (2013). Pengaruh kepuasan kerja dan loyalitas kerja terhadap organizational citizenship behavior pada karyawan PT. Surya Timur Sakti Jatim. Agora, l(1).

Waspodo \& Minadaniati. (2012). Pengaruh kepuasan kerja dan iklim organisasi terhadap organizational citizenship behavior (OCB) karyawan pada PT. Trubus Swadaya Depok. Jurnal Riset Manajemen Sains Indonesia, 3(1).

Wardani, A.K. dan Miftahun, N.S.(2012). Faktor kepribadian dan organizational citizenship behaviour pada Polisi Pariwisata. Humanitas, 9(2). 